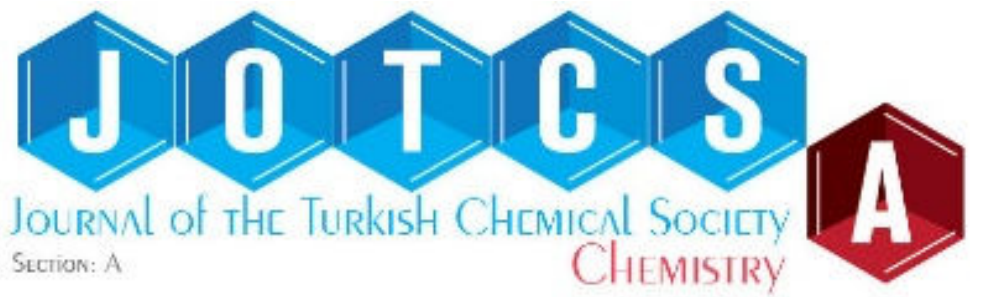

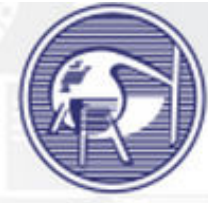

TURKISH

CHEMICAL SOCIETY

(This article was presented to the 28th National Chemistry Congress and submitted to JOTCSA as a full manuscript)

\title{
Production and Investigation of Controlled Drug Release Properties of Tamoxifen Loaded Alginate-Gum Arabic Microbeads
}

\author{
Onur Korkmaz ${ }^{1}$, Bernis Girgin ${ }^{1}$, Çağdaş Sunna ${ }^{1}$, Rukiye Yavaşer*1, Arife Alev Karagözler ${ }^{1}$ \\ ${ }^{1}$ Adnan Menderes University, 09010, Aydın, Turkey
}

\begin{abstract}
The entrapment of tamoxifen onto alginate-gum arabic beads and the production of controlled drug release was investigated in this study. The polymeric system that would provide the controlled release of tamoxifen was formed using alginate and gum arabic. In the first phase of the study, the optimization of the alginate-gum arabic beads production was conducted; then the study continued with drug entrapment experiments. Tamoxifen entrapment yield was found to be approximately $90 \%$ of initial tamoxifen concentration. In vitro drug release experiments were performed in simulated gastric juice and intestinal fluid where the tamoxifen release was $20 \%$ and $53 \%$ of the initial drug present, respectively. As a result of this study, it is expected that a valuable contribution to the field of controlled drug release system production is realized.
\end{abstract}

Keywords: Tamoxifen, alginate, gum arabic, bead, controlled drug release.

Submitted: July 4, 2016, Revised: August 4, 2016, Accepted: August 11, 2016.

Cite this: Korkmaz O, Girgin B, Sunna Ç, Yavaşer R, Karagözler A. Production and Investigation of Controlled Drug Release Properties of Tamoxifen Loaded Alginate-Gum Arabic Microbeads. Journal of the Turkish Chemical Society, Section A: Chemistry. $2016 ; 3(3): 47-58$.

DOI: $10.18596 /$ jotcsa.77290.

*Corresponding author: E-mail: ryavaser@gmail.com,tel: +902562128498. 


\section{INTRODUCTION}

Controlled drug release systems have a significant role in medicine. They are considered as useful systems that enable the drug to be more efficient. These systems have advantages such as decreasing the risk of harmful effects that may come from the drug and increasing the efficiency and availability of the drug compared to conventional drug applications (1). In controlled drug release systems, the drug is entrapped by the carrier. The carrier is required to release the drug in a desired manner during its voyage to the defined part of the body or when it reaches there.

Natural polymers have gained attention as suitable materials to produce controlled drug release systems (2). Alginate (Figure 1a) is a natural polysaccharide composed of a-1,4guluronic acid and $\beta$-D-mannuronic acid blocks. Guluronic acid residues are responsible for the gelation properties of alginate. Alginate is a water-soluble, linear, and polyanionic biopolymer obtained from brown algae and it is employed in numerous applications such as food, textile, pharmaceutical, cosmetic industries as stabilizers, thickening and gelling agents, and adhesives. Alginate is reported to be safe when it is taken by the oral route since it is nontoxic and biodegradable (3). Alginate can be gelled with $\mathrm{Ca}^{2+}$ anions easily. Gel beads, microparticles and nanoparticles can be synthesized from alginate alone or together with other polymers like chitosan, gelatin, and albumin. Gum arabic (Figure 1b) is a polysaccharide obtained from acacia tree. Similar to alginate, gum arabic finds usage in food and other industries.

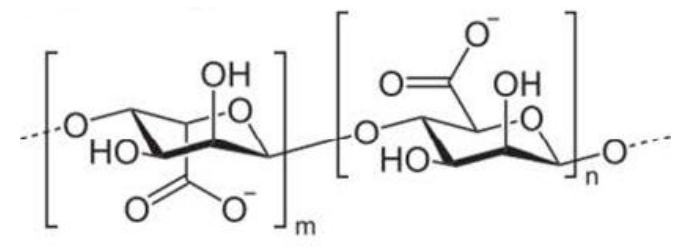

(a)

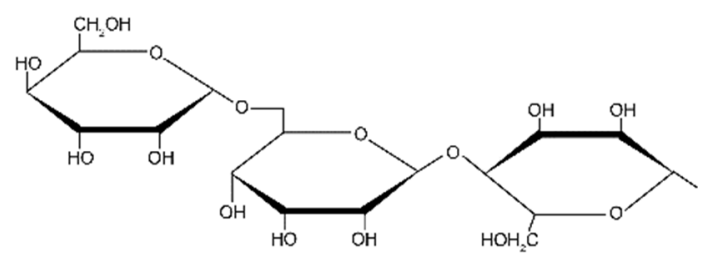

(b)

Figure 1. Molecular structures of alginate (a) (4) and gum arabic (b) (5).

Tamoxifen [(Z)-2-[4-(1,2-diphenylbut-1-enyl)phenoxy]- $N, N$-dimethyl-ethanamine, TMX] (Figure 2) is a synthetic drug used for cancer therapy. It is an antagonist for estrogen receptors in mammary tissue via its active metabolite hydroxytamoxifen (6). Antagonists attach to the cell receptor and act as a natural stimulator and prevent the natural response (7). TMX is being administrated to patients with different stages of breast cancer and although it is a very effective drug, in high doses it may lead some harmful developments such as endometrial cancer and tumor progression (8-9). Entrapment materials were synthesized for minimizing these disadvantageous effects to capture tamoxifen and deliver 
it to the tumor site. Polymeric micelles (10), nanoparticles (11-12), alginate/chitosan microparticles (13), and hydrogels (14) are examples of tamoxifen carriers.

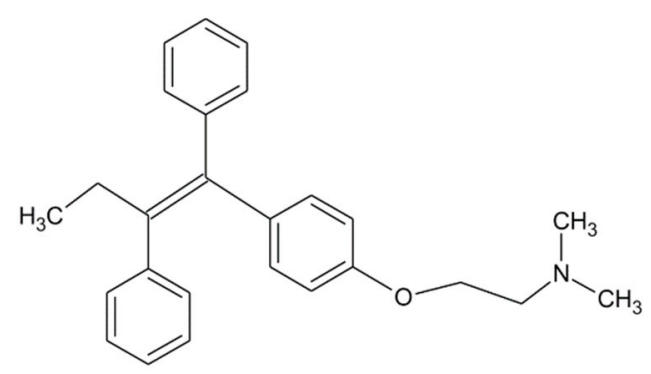

Figure 2. Chemical structure of tamoxifen molecule (15).

In this study, the entrapment of tamoxifen into alginate/gum arabic beads and in vitro controlled tamoxifen release was investigated. The aim of the study was to develop a new carrier for tamoxifen with a high entrapment yield and good carrier properties.

\section{MATERIALS AND METHODS}

\section{Materials}

Tamoxifen citrate, alginic acid sodium salt from brown algae (medium viscosity), $\mathrm{CaCl}_{2}$, gum arabic, ethanol, and $\mathrm{HCl}$ were purchased from Sigma (Steinheim, Germany). Tween 80 was obtained from Merck (Darmstadt, Germany) and $\mathrm{KCl}$ was obtained from Carlo Erba (Ronado, Italy). Phosphate buffer tablets (PBS) were purchased from Oxoid (Hampshire, England). All chemicals used were of analytical grade.

\section{Production of plain alginate-gum arabic beads}

Plain beads were prepared by ionic crosslinking method (16). Two hundred milligrams of alginic acid sodium salt was dissolved by stirring the solution at $200 \mathrm{rpm}$ at room temperature for $30 \mathrm{~min}$ in $20 \mathrm{~mL}$ distilled water. Gum arabic (100 mg) was added slowly and mixture was stirred for $30 \mathrm{~min}$ at $200 \mathrm{rpm}$ and sonicated for $5 \mathrm{~min}$. Alginate-gum arabic solution was added dropwise into continuously stirred (100 rpm) $5 \% \mathrm{CaCl}_{2}$ solution. The resulting beads were maturated for $1 \mathrm{~h}$, filtered, and washed with distilled water.

\section{Preparation of TMX entrapped alginate-gum arabic beads}

TMX entrapped beads were produced by adding $1.0 \mathrm{~mL}$ of TMX solution $(3 \mathrm{mg} / \mathrm{mL}$ in ethanol) into $20 \mathrm{~mL}$ of alginate solution ( $1 \%, \mathrm{w} / \mathrm{v})$ containing $100 \mathrm{mg}$ gum arabic. The 
Korkmaz et al., JOTCSA. 2016; 3(3): 47-58.

solution was mixed at $200 \mathrm{rpm}$ for $30 \mathrm{~min}$. The resulting solution was added dropwise into the crosslinker solution $\left(5 \% \mathrm{CaCl}_{2}\right)$ and the drug-entrapped beads were obtained (Figure 3 ). The beads were maturated for 1 hour, then filtered. All experiments were employed triplicate.

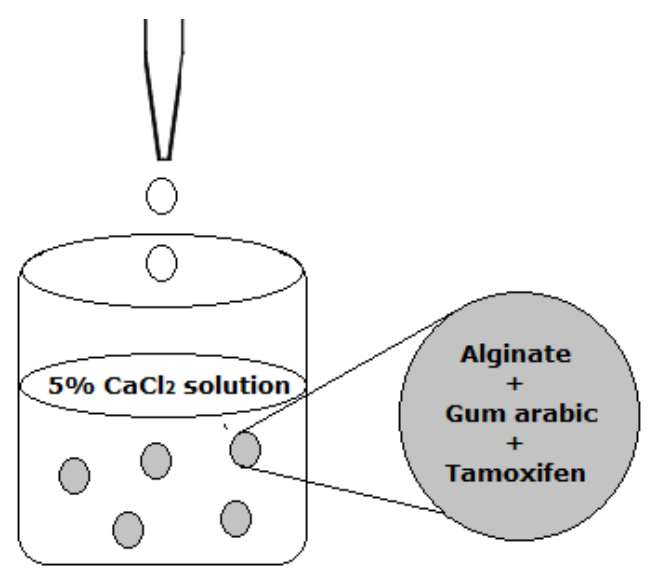

Figure 3. Production of TMX entrapped alginate-gum arabic beads.

\section{Entrapment efficiency (EE\%)}

Entrapment efficiency was calculated evaluating the drug content in the filtrate that indicates the untrapped TMX. Two $\mathrm{mL}$ of the filtrate was centrifuged at $18000 \mathrm{rpm}$ at $4{ }^{\circ} \mathrm{C}$ for $30 \mathrm{~min}$ in order to remove any suspended molecules and the absorbance of the supernatant was recorded at $276 \mathrm{~nm}$. The EE\% of beads was calculated from the formula given below:

$$
\mathrm{EE}=\frac{\text { Total TMX added }(\mathrm{mg})-\text { Untrapped TMX }(\mathrm{mg})}{\text { Total TMX added }(\mathrm{mg})} \times 100
$$

\section{In vitro release studies}

In vitro release of TMX from alginate-gum arabic beads was carried out at $37 \pm 1{ }^{\circ} \mathrm{C}$ in 50 $\mathrm{mL}$ of simulated gastric fluid (SGF) (mixture of $100 \mathrm{~mL} 0.2 \mathrm{M} \mathrm{HCl}$ and $82.8 \mathrm{~mL} 0.2 \mathrm{M} \mathrm{KCl}$, $\mathrm{pH} 1.5$ ) and $103 \mathrm{~mL}$ of simulated intestinal fluid (SIF) (100 mL PBS solution containing 3.0 $\mathrm{mL}$ of $1 \%$ Tween $80, \mathrm{pH} 7.4$ ) separately. At 30 min intervals, $2.0 \mathrm{~mL}$ aliquots were sampled out. Prior to absorbance measurements at $276 \mathrm{~nm}$, the samples were centrifuged at 18000 $\mathrm{rpm}$ at $4^{\circ} \mathrm{C}$ for $30 \mathrm{~min}$ to remove any suspended particles. The percent of TMX released was calculated and plotted versus time. 
Korkmaz et al., JOTCSA. 2016; 3(3): 47-58.

The release profile of TMX was also evaluated in SGF and SIF consecutively. Beads were transferred into $100.0 \mathrm{~mL}$ of SGF and allowed to stir at $150 \mathrm{rpm}$ for $2 \mathrm{~h}$. At each $30 \mathrm{~min}$ intervals, $2.0 \mathrm{~mL}$ of the medium was sampled and centrifuged at $18000 \mathrm{rpm}$ at $4{ }^{\circ} \mathrm{C}$ for 30 min and the absorbance was recorded at $276 \mathrm{~nm}$. Then, beads were removed from SGF and transferred into $103 \mathrm{~mL}$ of SIF and stirred for another $3 \mathrm{~h}$. The release procedure was followed in intestinal medium for 22 hours. Release experiments were conducted at $37{ }^{\circ} \mathrm{C}$ in triplicate. The amount of released tamoxifen was calculated from TMX standard curve.

\section{RESULTS AND DISCUSSION}

In this study, an anticancer agent, Tamoxifen, was selected as the model drug which was further entrapped by ionic crosslinking method in alginate and gum arabic natural polymers. Alginate-gum arabic beads were produced and their abilities to release the anticancer drug Tamoxifen in a controlled manner were investigated. A polysaccharide blend was prepared composed of alginate and gum arabic. Spherical beads were obtained about $3 \mathrm{~mm}$ size (Figure 4).

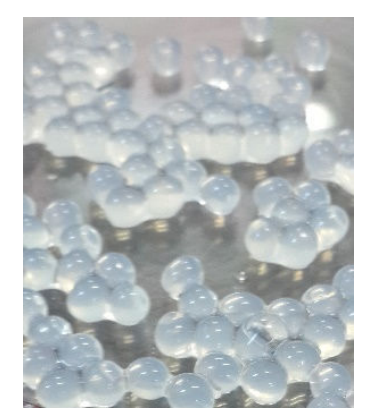

Figure 4. TMX entrapped alginate-gum arabic beads.

TMX entrapment efficiency was calculated using the TMX standard curve which is demonstrated in Figure 5. According to the results from entrapment studies, approximately $90 \%$ of TMX was entrapped in the beads. 


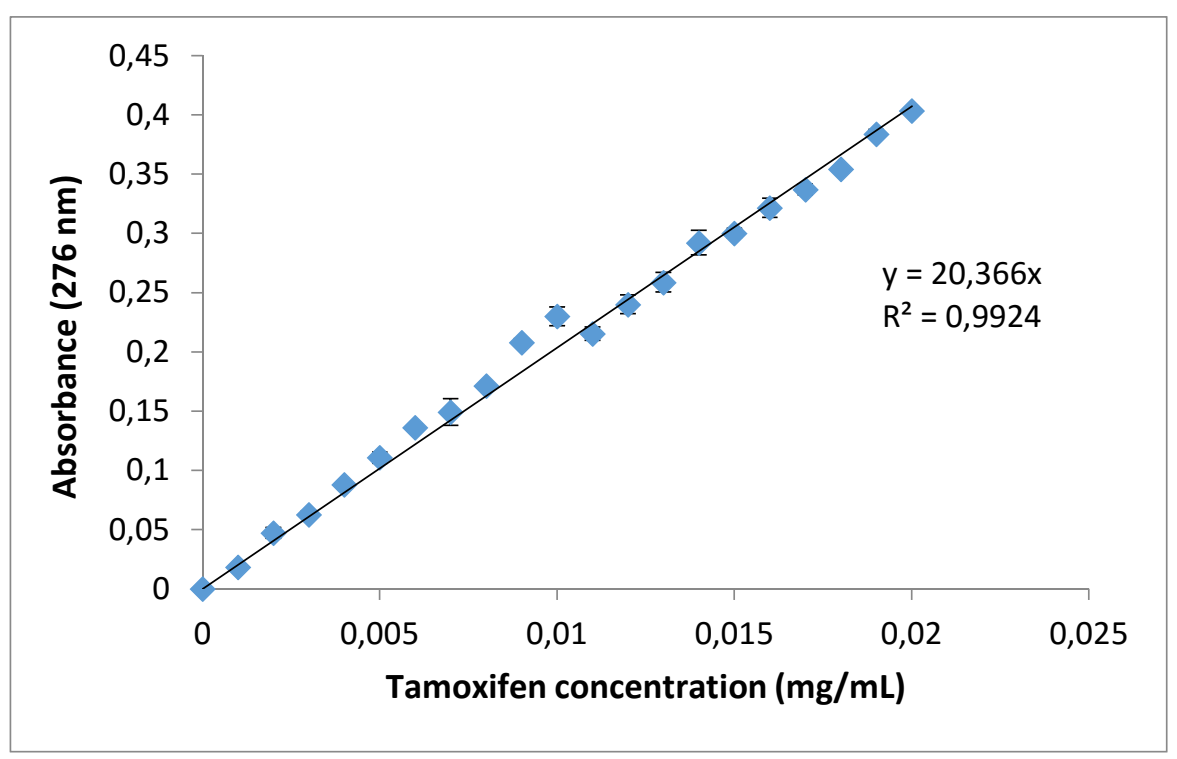

Figure 5. TMX standard curve.

The extend of drug release in in vitro stomach (gastric) and small intestine (intestinal) media were measured using $\mathrm{pH} 1.5$ and $\mathrm{pH} 7.4$ for 24 hours. The results revealed that the release of the initial TMX present in beads was $20 \%$ at $\mathrm{pH} 1.5$ whereas it was $53 \%$ at $\mathrm{pH}$ 7.4. The release ratio did not change significantly after five hours. The release profiles in SGF and SIF are shown in Figures 6 and 7.

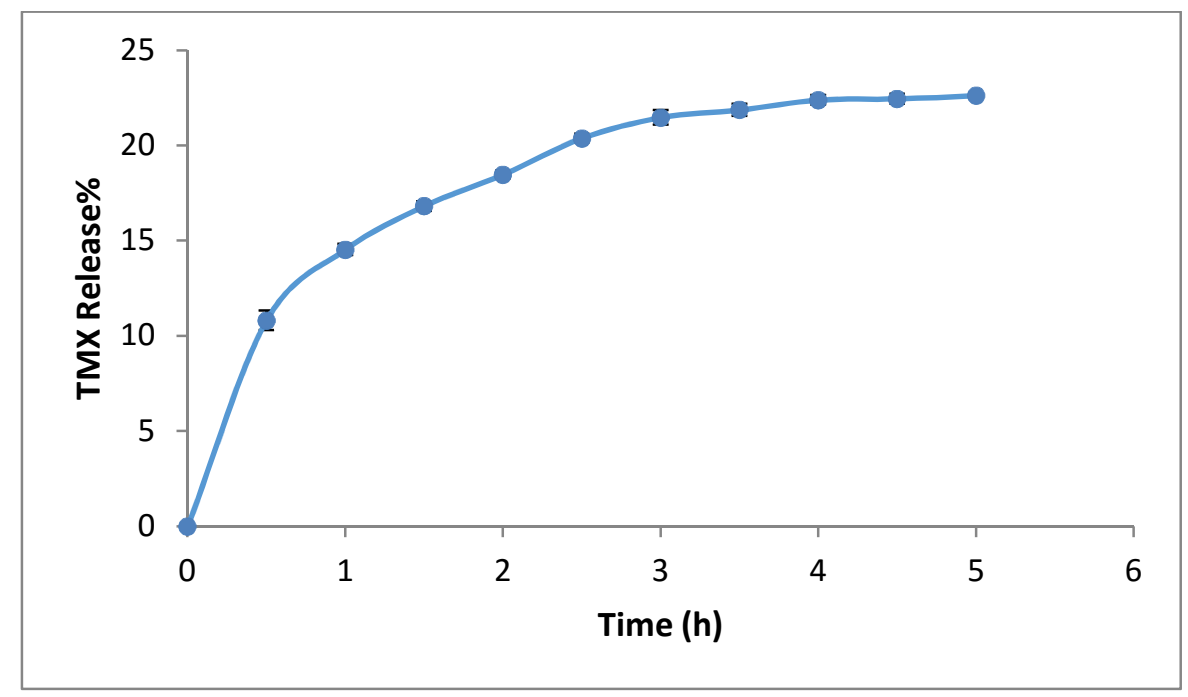

Figure 6. The release profile of TMX entrapped alginate-gum arabic beads in SGF.

For in vitro drug release studies, the physiological conditions such as $\mathrm{pH}$ and temperature are important. Simulated gastric fluid $(\mathrm{pH} \mathrm{1.5)}$ and simulated intestinal fluid $(\mathrm{pH} 7.4)$ are usually preferred as drug release media. The temperature of the release medium is generally chosen as $37^{\circ} \mathrm{C}$ since it is the temperature of the human body. By this way, the results reflect the behavior of drug carrier particle in the body. 


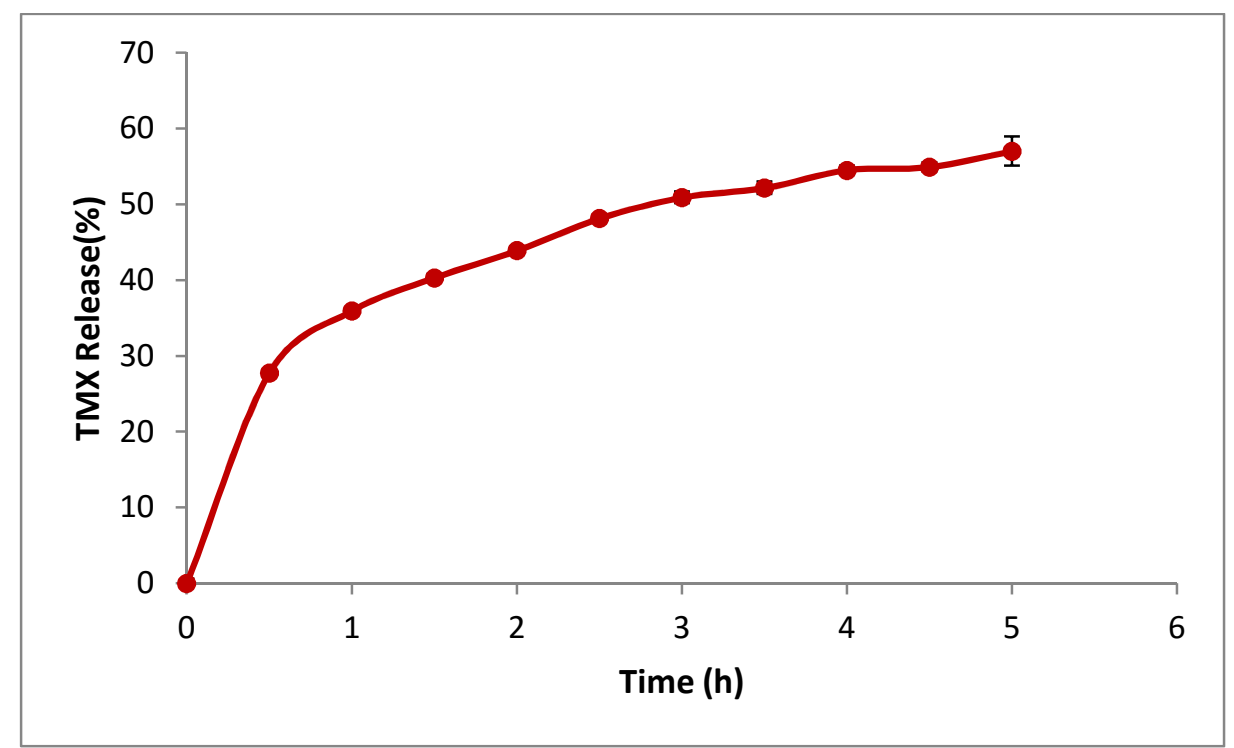

Figure 7. The release profile of TMX entrapped alginate-gum arabic beads in SIF.

The release percentage in SGF was lower compared to SIF. This may be explained by the swelling behaviors of beads in these media. Alginate-gum arabic beads might have the capability to swell and release the drug entrapped slightly in gastric medium. However, they might swell more in intestinal media and also disintegrate and allow the drug to become free (17). Disintegration may be the major reason of higher release profile since calcium favors to form calcium phosphate (18), as it is observable that the release medium was turbid during the studies in SIF.

The consecutive TMX release in SGF and SIF was also studied and was illustrated in Figure 8. The results were similar to individual procedures applied in SGF and SIF alone. However, this treatment was assumed to be more convenient to mimic the stages that a drug passes in the human body. As seen in Figure 8, 30\% of TMX was released in SGF and when the beads were transferred into SIF, with a shift of $10 \%$ in $30 \mathrm{~min}, 60 \%$ of cumulative TMX release was observed after $5 \mathrm{~h}$. 


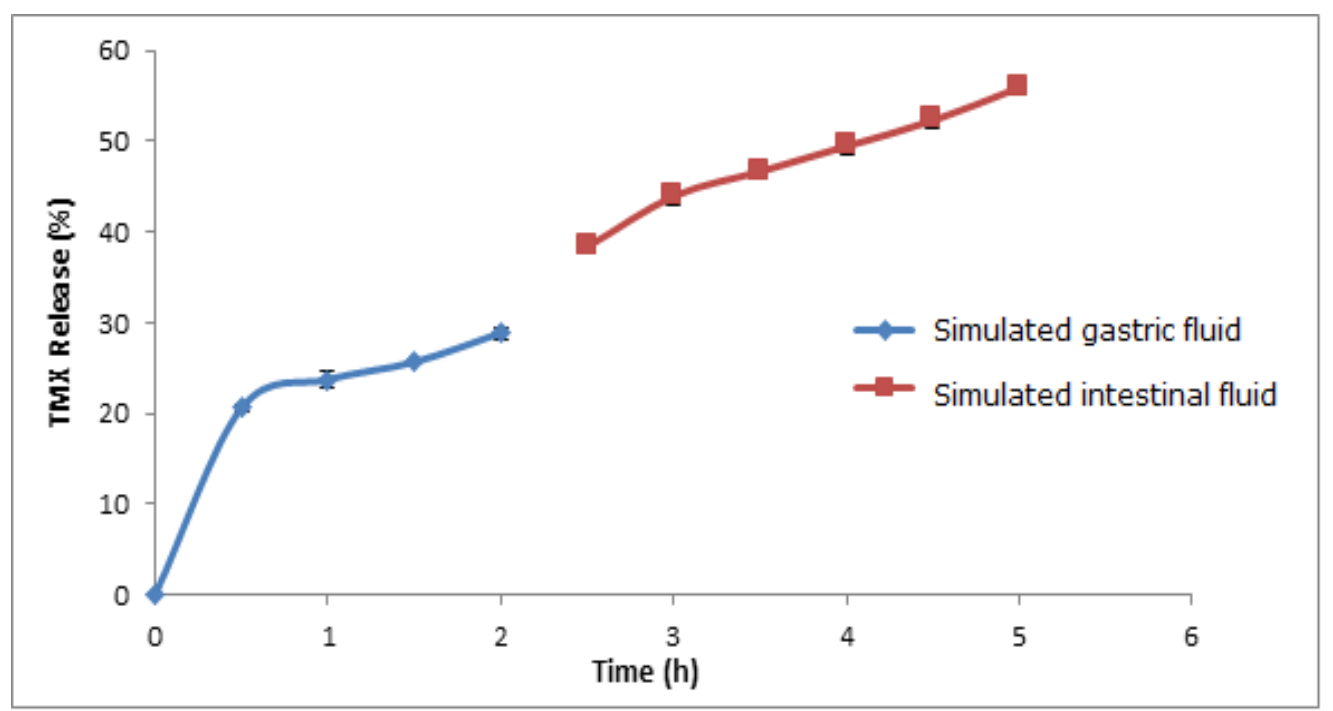

Figure 8. Consecutive TMX release from alginate-gum arabic beads in SGF and SIF.

\section{CONCLUSION}

The polymeric system that provided the controlled release of Tamoxifen was built using alginate and gum arabic natural polymers. In vitro drug release experiments were conducted in simulated gastric juice and intestinal fluid using the tamoxifen entrapped beads. It may be concluded that results presented here indicates that it is possible to manufacture a working drug carrier and release system for Tamoxifen using alginate and gum arabic natural polymers. The study needs further investigation for production of the drug carrier in real time manufacturing plants.

\section{ACKNOWLEDGEMENTS}

The authors thank to Adnan Menderes University Research Fund for the financial support of this study under a project (Project Number: FEF 16006). 


\section{REFERENCES}

1. Kumar R, Majeti NV. Nano and microparticles as controlled drug delivery devices. Journal of Pharmaceutical Sciences. 2000; 3(2):234-258. http://www.ncbi.nlm.nih.gov/pubmed/10994037.

2. Jana S, Ghandi A, Sen KK, Basu SK. Natural Polymers and their application in drug delivery and biomedical field. 2011; 1(1):16-27. http://www.pharmascitech.in/admin/php/uploads/6_pdf.pdf.

3. Kalia S., Averous L. Biopolymers: Biomedical and Environmental Applications. Scriven Publishing LLC., Massachusetts. 2011. ISBN: 978-0-470-63923-8.

4. Guarino V, Caputo T, Altobelli R, Ambrosio L. Degradation properties and metabolic activity of alginate and chitosan polyelectrolytes for drug delivery and tissue engineering applications. AIMS Materials Science. 2015; 2(4): 497-502. DOI: 10.3934/matersci.2015.4.497.

5. http://www.justpaint.org/the-science-behind-qor/

6. Ogura K, Ishikawa Y, Kaku T, Nishiyama T, Ohnuma T, Muro K, Hiratsuka A. Quaternary ammonium-linked glucuronidation of trans-4-hydroxytamoxifen, an active metabolite of tamoxifen, by human liver microsomes and UDP-glucuronosyltransferase 1A4. Biochemical Pharmacology. 2006; 71(9): 1358-1369. DOI: 10.1016/j.bcp.2006.01.004.

7. Jensen, SC, Peppers, MP. Pharmacology and drug administration for imaging technologists. Elsevier Health Sciences, 2013. ISBN: 978-0-323-03075-5.

8. MacGregor JI, Jordan VC. Basic guide to the mechanisms of antiestrogen action. Pharmacological Reviews. 1998; 50(2): 151-196. PMID: 9647865.

9. Brigger I, Chaminade P, Marsaud V, Appel M, Besnard M, Gurny R, Couvreur P. Tamoxifen encapsulation within polyethyleneglycol-coated nanospheres. $A$ new antiestrogen formulation. International Journal of Pharmaceutics. 2001; 214(1): 37-42. DOI:10.1016/S03785173(00)00628-1.

10. Cavallaro G, Maniscalco L, Licciardi M, Giammona G. Tamoxifen-loaded polymeric micelles: preparation, physico-chemical characterization and in vitro evaluation studies. Macromolecular Bioscience. 2004; 4(11): 1028-1038. DOI: 10.1002/mabi.200400089.

11. Chawla JS, Amiji MM. Biodegradable poly ( $\varepsilon$-caprolactone) nanoparticles for tumor-targeted delivery of tamoxifen. International Journal of Pharmaceutics. 2002; 249(1):127-138. DOI: $10.1016 /$ S0378-5173(02)00483-0.

12. Maji R, Dey NS, Satapathy B., Mukherjee B, Mondal S. Preparation and characterization of Tamoxifen citrate loaded nanoparticles for breast cancer therapy. International Journal of Nanomedicine. 2014; 9, 3107. DOI:10.2147/IJN.S63535. 
Korkmaz et al., JOTCSA. 2016; 3(3): 47-58.

13. Coppi G, Iannuccelli V. Alginate/chitosan microparticles for tamoxifen delivery to the lymphatic system. International Journal of Pharmaceutics. 2009; 367(1): 127-132. DOI:10.1016/j.ijpharm. 2008.09.040.

14. Shaker DS, Shaker MA, Klingner A, Hanafy MS. In situ thermosensitive Tamoxifen citrate loaded hydrogels: an effective tool in breast cancer loco-regional therapy. Journal of Drug Delivery Science and Technology. 2016; 35:155-164. DOI:10.1016/j.jddst.2016.05.007.

15. Yarman A, Scheller FW. The first electrochemical MIP sensor for tamoxifen. Sensors. 2014; 14(5): 7647-7654. DOI: 10.3390/s140507647.

16. Malakar M,Nayak AK, Pal D, Jana P. Potato starch-blended alginate beads for prolonged release of tolbutamide: Development by statistical optimization and in vitro characterization. Asian Journal of Pharmaceutics. 2013; 7: 43-51. DOI: 10.4103/0973-8398.110935.

17. Nayak AK, Das B, Maji R. Calcium alginate/gum arabic beads containing glibenclamide: Development and in vitro characterization. International Journal of Biological Macromolecules. 2012; 51(5): 1070-1078. DOI:10.1016/j.ijbiomac.2012.08.021.

18. Lee, B. J., Min, G. H., \& Kim, T. W. Preparation and in vitro release of melatonin-loaded multivalent cationic alginate beads. Archives of Pharmacal Research. 1996; 19(4): 280-285. DOI: $10.1007 / B F 02976241$. 
Türkçe Öz ve Anahtar Kelimeler

\section{Tamoksifen Yüklü Aljinat-Gam Arabik Mikroboncukların Üretimi ve Kontrollü İlaç Salımı Özelliklerinin İncelenmesi}

Onur Korkmaz, Bernis Girgin, Çağdaş Sunna, Rukiye Yavaşer, Arife Alev Karagözler

Öz: Bu çalışmada aljinat-gam arabik boncuklarına tamoksifenin tutturulması ve kontrollü ilaç salımının üretilmesi araştırıımışır. Tamoksifenin kontrollü salımını sağlayacak polimerik sistem aljinat ve gam arabik kullanılarak oluşturulmuştur. Çalışmanın ilk kısmında, aljinatgam arabik boncuklarının en uygun şartlarda elde edilmesi sağlanmıştır; ardından çalışma ilaç tutuklama deneyleriyle devam etmiştir. Tamoksifen tutuklaması ilk tamoksifen derişiminin yaklaşık \%90'ı kadar tespit edilmiştir. In vitro ilaç salım deneyleri yapay mide ve bağırsak ortamına benzer ortamlarda gerçekleştirilmiştir ve tamoksifen salımı baştaki ilaç derişiminin sırayla \%20'si ve \%53'ü olarak bulunmuştur. Bu çalışmanın sonucu olarak, kontrollü ilaç salımı sistem üretimine değerli bir katkıda bulunulması beklenmektedir.

Anahtar kelimeler: Tamoksifen, aljinat, gam arabik, boncuk, kontrollü ilaç salımı.

Gönderilme: 4 Temmuz 2016, Düzeltme: 4 Ağustos 2016, Kabul: 11 Ağustos 2016. 
Korkmaz et al., JOTCSA. 2016; 3(3): 47-58.

RESEARCH ARTICLE 